\title{
Practicing Mail Art in Visual Arts Course, and Evaluation of the Artworks of Students
}

\author{
Süreyya Genç ${ }^{*}$ \\ ${ }^{1}$ Department of Fine Arts Education, Faculty of Education, Bartın University, Turkey \\ *Correspondence: Faculty of Education, Department of Fine Arts Education, Bartın University, Turkey. E-mail: \\ sryygenc@gmail.com
}

Received: January 27, 2019

Accepted: February 15, 2019 Online Published: February 20, 2019

doi:10.5430/wje.v9n1p255

URL: https://doi.org/10.5430/wje.v9n1p255

\begin{abstract}
Purpose of this study is to identify the contribution of the educational use of mail art to Visual Arts Course. This study has been designed to attain an idea from the activity samples, in order for a more effective and eager teaching of the course. This is a descriptive study based on case study model. The study group consists of 4th-grade students from a randomly selected elementary school located in Bartın province of Turkey in 2018-2019 school year. Having been carried out with the participation of 43 students, this study is considered significant; as it enables the students to follow art activities at early ages and introduce them to the concepts of art, artist and process of art-making; emphasizes variety of activities to be applied in visual arts course; and serves as a sample for further researches. Besides, there was no research found on the use of mail art in visual arts course, which makes this study necessary. The study lasted two course hours and the designs of students were collected at the end. Upon consulting expert opinions, designs of the students were subjected to a content analysis in terms of the techniques and objects used, and the choice of subjects. Then the obtained data were tabulated and interpreted descriptively. Based on the observations of the researcher, the most remarkable findings of the study are accepted to be the positive effect of planning an activity different from the regular course format for students; as well as witnessing their enthusiasm, joy, interest, happiness and the authentic works they designed.
\end{abstract}

Keywords: mail art, visual arts course, paintings of children, creativity

\section{Introduction}

Mail art is an international network where every creative individual can participate with any art object, which is possible to send by letter. Being an experimental, expressionist, and entertaintment art, different sketches or objects can be used in mail art; such as handmade postcards, digital prints, photocopies, collages, paintings, or drawings (Güneş, 2014, p. 8). This artistic activity, which is also referred to as correspondence art or arte postale, derived from the tradition of letter, which dates back in early history, and turned into a creative branch closer to visual arts. Although these interesting practices are handled within the context of contemporary art and they go far from the concept of conventional letters, mail art may involve certain features of the letter we know (Alaca, 2014, p. 77). According to Phillpot (1995); "Mail art, simply defined, is art that utilizes the postal service, or, in a secondary manifestation, is art that takes a form relating to postal products or apparatus - for example, artists' postage stamps and artists' rubber stamps."

"Whereas makers of most mail art take vast liberties with the forms and functions of their modes of communication essentially seeking the limit to what the post office recognizes as "mail" - the stamp implies a rigid codification of form and function" (Frank, 1981).

"It is difficult to pinpoint the moment when artists' correspondence became correspondence art. By the end of the late 1950s, the three primary sources of correspondence art were taking shape. In North America, the New York Correspondence School was in its germinal stages in the work of artist Ray Johnson and his loose network of friends and colleagues" (Friedman, 1995). According to Held (1996), the techniques of mail art, which enabled the widespread of Dadaist art philosophy, were used by the futurists, surrealists, and Dadaists in the early $20^{\text {th }}$ century. According to Doris Bell, mail art was initiated in 1916 with Marcel Duchamp. Delivering his thoughts through a 
postcard led to the development of this worldwide network. In 1950s, sending daily materials through mail began with Ray Johnson, known as the father of postal art (Güneş, 2014, p. 9). Marcel Duchamp, Kurt Schwitters, and Italian futurists are the pioneers of mail art; however, the international widespread of this art happened in 1960s, with the help of Fluxus, Neo-realism, Gutai group and Roy Johnson's activities. The letters sent by Roy Johnson through a postal network he created is known as New York Correspondence School of Art. The founder exhibitions of mail art are the exhibitions held in the Whitney Museum Correspondence Art (1970) and in the area allocated for mail art at Paris Biennial (Alaca, 2014, p. 75). "In the 1970s, mail art became an impressive movement, attracting artists from around the world. Between 1970 and 1980, the number of exhibitions increased from two to 425" (Held, 1986; cited in Gangadharan, 2009). According to Dunkin-Hubby (2016), mail art, which is the exchange of objects and ideas, is a phenomenon that is in constant transformation in the course of time.

It is possible to see many projects, exhibitions, and biennals held in our country on mail art, just like the numerous activities on international platform. It is basically the process of designing a postcard and/or an envelope by an artist based on a certain theme or not; stamping, and its delivery definitely through mail.

Recently, mail art has turned into a fresh way of thought accelerating the international communication, which offers us limitless alternatives, and enabling us to easily experience this form of art. The increase of the interest and participation in mail art may enable us to open to the world and gain a rather modern perception (Alaca, 2014, p. 84).

Based on this interest, the mail art is believed to make a contribution to art education, especially while introducing children with current art applications, and increasing their interest in art activities, as well as the course. Being regarded as an unusual activity different from the regular activities held in Visual Arts course, mail art will prevent the course from being monotonous and the students will eagerly be a part of an active learning process. It is of great importance to involve different activities so that the course of Visual Arts may gain a modern shape.

The most significant duty of art teachers is to realize the activities that appeal to students, and to motivate them so that they develop fondness towards these activities and learn easier. Because, no artistic activity will be achieved as long as the student is reluctant. It is of vital importance for the student to be interested in the subject and the activity. A visual art course which fails to attract the attention of the student will not be able to achieve its objective. All visual art activities that are left alone cannot be expected to attract all of the students' attention (Yilmaz, 2010, p. 199).

Organization, order, and presentation of the course materials must be variated in order to attract students' attention and arouse curiosity. They must be given the opportunity to express their knowledge, experiences, ideas, and opinions freely, through various ways. It must be guaranteed that the student is actively present in class (Yilmaz, 2010, p.204-205). An active student will learn more easily and become more creative. Creative thinking plays a crucial role in raising qualified individuals. "The educational opportunities that a child has provides the affordances for reaching his or her human potential" (Siegesmund, 1998).

Conrad identifies creativity as "the birth of a process of creative search, research, and discovery that involves concept, feeling, and imagination; as well as an effective metaphor emerging from perception and associated to sensations and emotions". San (1977), on the other hand, stated that the emergence of this metaphor in visual arts is the process of transferring images from cognitive and pre-cognitive stages into a concrete form within the productive thinking processes after finding the most appropriate material for the transformation of the images into new regulations (cited in Yolcu, 2010, p. 49). According to Wright (2003), art involves a distinct way of knowing-thinking that integrates thinking, feeling, and action. Children gain a special form of literacy through fine arts, where they can put the action into practice (cited in Fox \& Schirmacher, 2014, p. 33).

Developing unusual, effective, and even funny solutions to problems encountered throughout life is only possible through creative thinking. Therefore, creativity is a process needed the most by people today (Yolcu, 2010, p. 31). "In the 21 st century, it is apparent that students need to be prepared for a new information age and that educational interventions in art education for all students that foster creative thinking, imagination, and innovation are important for generating solutions to real life problems both now and in the future" (Zimmerman, 2009). Additionally, students must be given the opportunity to think over the works they created in Fine Arts course. This way, the students will have the advantage of raising knowledge, learning permanently, and recognizing art, the artist and the work during school years and in the future (Yılmaz, 2009, p. 15). According to Kehnemuyi (1995, p. 17 - 18), major changes have happened in art education and it has rather become a tool by which the child can express his/her ideas and feelings. By means of showing them how to do so, today, teachers provide children with the opportunity to paint about exciting subjects, rather than simply teaching them how to paint. In other words, children are set free. There are numerous studies indicating that a child's learning capacity depends on his/her desire and interest at that moment. 
Hurwitz and Day (1995, p. 38-40) highlights the fact that children must be able to see the ways of learning about works of art in a modern class of visual arts; as well as performing their own. Because they are widely eager and enthusiastic about these learning activities (Özsoy, 2003, p. 118).

Based on this perspective, the answer will be sought to the question of how the use of mail art activity in Visual Arts is reflected in the works created by students in terms of the technique and objects used, as well as the choice of subject; and what are the opinions of students on this activity. According to Atalay and Gürses (2016, p. 635), there are no data available on the teaching of mail art, which is not quite known in our country, at educational institutions. Therefore, this research is believed to make a contribution to the literature.

\section{Method}

\subsection{Model of the Study}

This is a qualitative research, analyzing the reflection of mail art activity to the works of $4^{\text {th }}$ grade elementary school students. The case study model has been used in the research as a qualitative research method; as well as the holistic single case study design, which focuses on a single unit or case (Paker, 2015, p. 123). According to Punch (2005, p. 144), the sample case study aims to understand the case deeply, in its natural environment, and by considering its complexity and context. According to Merriam (2015, p. 39), these studies are in search of meaning and understanding, as in other qualitative research methods, where the primary data collector and analysis tool is the researcher himself/herself. According to Yıldırım and Şimşek (2003, p. 191), on the other hand, a case study is based upon the questions of "how" and "why", and an elaborate analysis of the case is its most prominent feature. "Information collected through such arrangements is only valid for the analysis subject unit, and does not attempt to generalize anything beyond that. However, a generalizability can also be achieved by increasing the number of cases analyzed" (Karasar, 2008, p. 86). Purpose of the study here is "to perform analytical, generalizations on a population, instead of statistical; in other words, to establish theories or make theoretical propositions. In this sense, there are no fundamental differences in technique between the experimental and case studies" (Yıldırım \& Şimşek, 2003, p. 193). In the light of this information, a particular group was thoroughly analyzed and the obtained data is presented without any generalization concerns.

\subsection{Study Group}

Participants of the study consist of 4th-grade students from a randomly selected elementary school located in Bartin province of Turkey in 2018-2019 school year fall semester. The study was conducted with a total of 43 students, 24 of them being female and 19 male students.

Table 1. Gender Distribution of Students Participating in the Study

\begin{tabular}{lcc}
\hline Gender & $\mathrm{n}$ & $\%$ \\
\hline Male & 24 & 55.81 \\
Female & 19 & 44.19 \\
Total & 43 & 100 \\
\hline
\end{tabular}

\subsection{Data Collection}

Today, the transformation of applications based on case studies stands out as a result of the opportunities brought by technology. Reflecting a visually existing situation is often more effective and faster than the textual or semantic readings related to the case. Considering that visuals are the best ways of telling, it is possible to create a more qualified sphere of influence with a visual in the conditions that can be listed as creating a sense of the situation, creating an impact on the viewer and seeing the reflections in tangible results (Erişti, 2016, p. 164). Based on this information, $4^{\text {th }}$ grade elementary school students in 2018 - 2019 school year fall semester were asked to design envelopes within the context of mail art, in order to obtain data of the study. The first hour of this two-hour course was allocated to the introduction and explanation of mail art to the students; as well as reviewing examples. They were asked to bring their color paints, waste materials, and adhesives the following week. The envelopes to be designed by the students were provided by the researcher. In the second hour, the envelopes were handed to the students by the researcher and then designed by the students with the materials they brought. Students were completely free on the subject of design. At the end of the study, the students were asked to explain what they wanted to express in their work with their own words, which were noted by the researcher. 


\subsection{Data Analysis}

The designs obtained at the end of the study were interpreted as descriptive, in terms of material selection, subject, objects drawn, and their expression, by consulting to expert opinions. According to Paker (2015, p. 127), opinions of other researchers working in the same field can also be consulted, which is one of the most frequently used methods to improve reliability in such studies.

Being a form of data analysis, digitization of qualitative data allows a more fair interpretation (Yıldırım \& Şimşek, 2003 , p. 177), for which the frequency and percentages obtained from the data of mail artworks of students were calculated and converted into tables. Students' responses to the question on mail art were coded as S1, S2, S3,..., S43. According to Yildırım and Şimşek (2003, p. 158-159), direct quotations can be used in the descriptive analysis to reflect the views of the interviewees or observed individuals effectively. These quotations are interpreted, and cause-and-effect relationships are reviewed, so as to reach certain conclusions. For this reason, students' own statements and practice studies are also included in the study.

\section{Findings and Discussion}

In this section, the findings of the study data were digitized and converted into tables. The findings are interpreted as descriptive, in line with two sub-objectives. The findings were discussed under the headings as; the findings regarding the reflection of mail art practice in visual arts course in the works of students; and the findings obtained from the students' opinions on mail art.

3.1 Findings Obtained with Regard to the Reflection of Mail Art Practice in Visual Arts Course in the Works of Students

Tablo 2. Distribution of Preferred Technique of Students in Envelope Design

\begin{tabular}{lcc}
\hline Technique & $\mathrm{f}$ & $\%$ \\
\hline Pastel Painting Technique & 2 & 4.66 \\
Charcoal Drawing Technique & 1 & 2.33 \\
Mixed Technique & 19 & 44.18 \\
Felt Marker Technique & 7 & 16.27 \\
Dry Paint Pencil Technique & 3 & 6.98 \\
Watercolor Technique & 11 & 25.58 \\
Total & 43 & 100 \\
\hline
\end{tabular}

Students participating in the study are found to use different techniques in the envelope designs, as seen in Table 2. It is observed that the students' mostly preferred mixed technique by $44.18 \%$. This is followed by the watercolor technique with $25.58 \%$. According to Table 2, charcoal drawing is the least preferred technique.

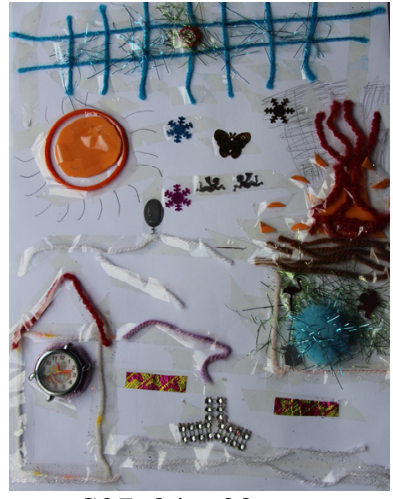

a. $\mathrm{S} 37,24 \times 32 \mathrm{~cm}$, mixed technique

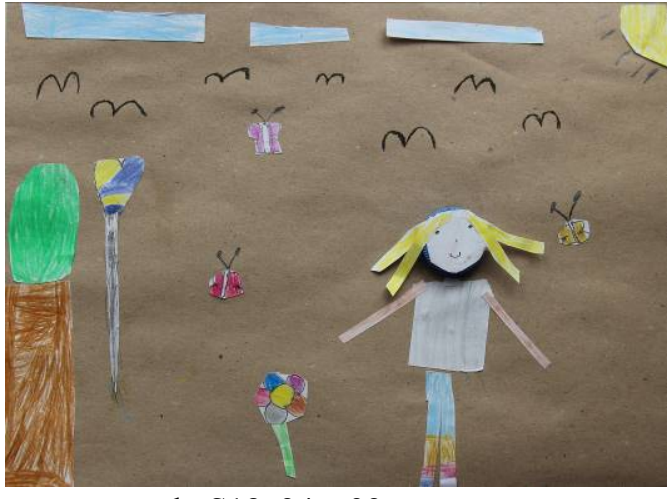

b. S18, 24 x $32 \mathrm{~cm}$, mixed technique

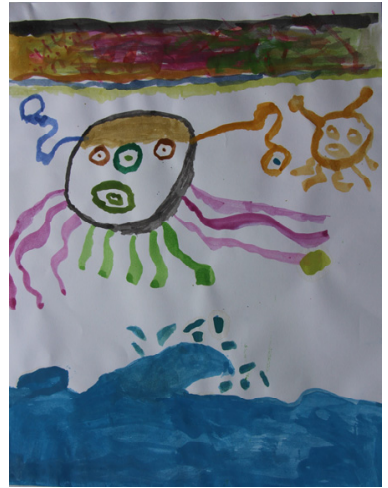

c. $\mathrm{S} 27,24 \times 32 \mathrm{~cm}$, watercolor technique

Figure 1. Works of Students with Different Techniques 
In figure 1. $a$ and $b$, it can be observed that students used a variety of waste materials in their works. The work of mail art provided under the Figure 1.c was made with watercolor, which is the second most preferred technique. The use of waste material and the detailed drawing efforts of the students who designed the whole surface of the envelope is remarkable.

Table 3. Distribution of Students' Status of Using the Envelope They Designed

\begin{tabular}{lcc}
\hline Use of Envelope & $\mathrm{f}$ & $\%$ \\
\hline One Side & 32 & 74.42 \\
Both Sides & 11 & 25.58 \\
Total & 43 & 100 \\
\hline
\end{tabular}

According to Table 3,74.42\% of the students designed both sides of the envelopes they used in mail art; while $25.58 \%$ designed only the front. In Table 3, it is found that most of the students preferred to design only one side of the envelope.
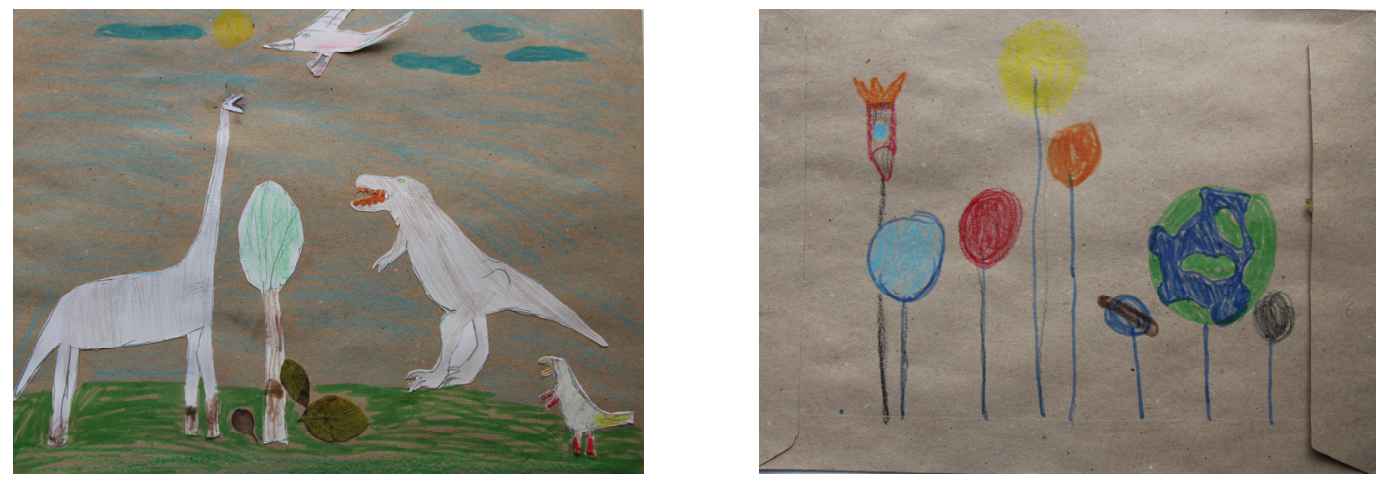

a. S16, 24 x $32 \mathrm{~cm}$, mixed technique
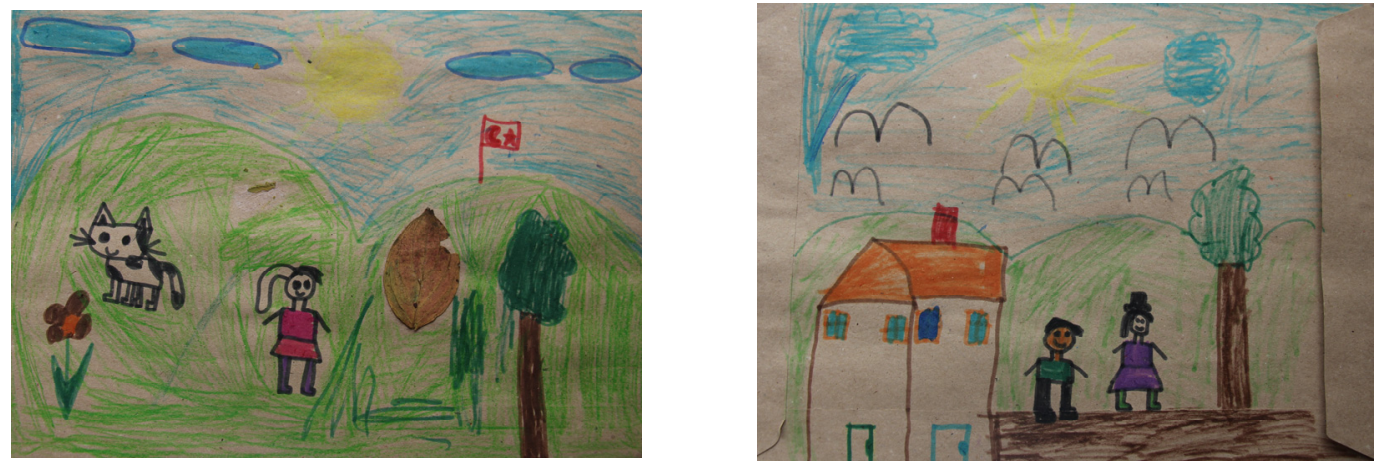

b. $\mathrm{S} 13,24 \times 32 \mathrm{~cm}$, mixed technique

Figure 2. Works of Students with Both Sides of the Envelope Designed

Majority of the students designed both sides of the envelope. While some students used the same subject matters to paint both sides, the others picked different subjects. As seen in Figure 2.a, there are dinasours on the front and planets at the back. In Figure 2.b, on the other hand, the student preferred to paint landscape in both sides. 
Table 4. Distribution of Subject Matters Preferred by Students While Designing the Envelope

\begin{tabular}{lcc}
\hline Subjcet Matter & $\mathrm{f}$ & $\%$ \\
\hline Marine & 3 & 6.97 \\
Dinosaurs & 1 & 2.33 \\
Snowman & 2 & 4.65 \\
Landscape-Nature & 12 & 27.90 \\
War & 2 & 4.65 \\
Health & 1 & 2.33 \\
Love & 1 & 2.33 \\
Intangible & 18 & 41.86 \\
Decoration & 2 & 4.65 \\
Space & 1 & 2.33 \\
Total & 43 & 100 \\
\hline
\end{tabular}

Table 4 reveals that $41.86 \%$ of the students preferred a tangible subject matter while designing the envelope. The second preferred subject is found to be landscape-nature drawings by $27.90 \%$, which is followed by a marine theme by $6.97 \%$. Then the students respectively chose to paint snowman by $4.65 \%$; decorations by $4.65 \%$, dinasours by $2.33 \%$; health by $2.33 \%$; love by $2.33 \%$; and space by $2.33 \%$.

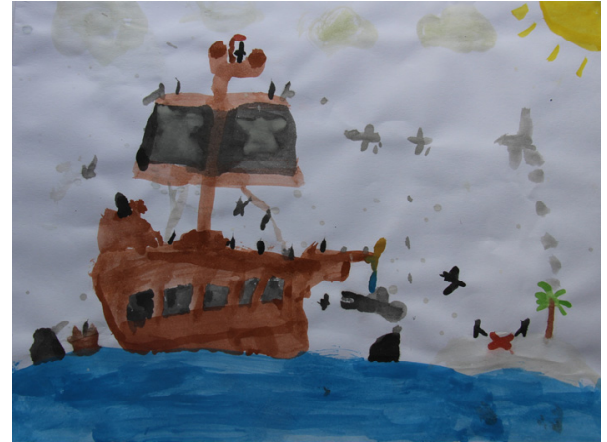

a. S31, $24 \times 32$, watercolor technique

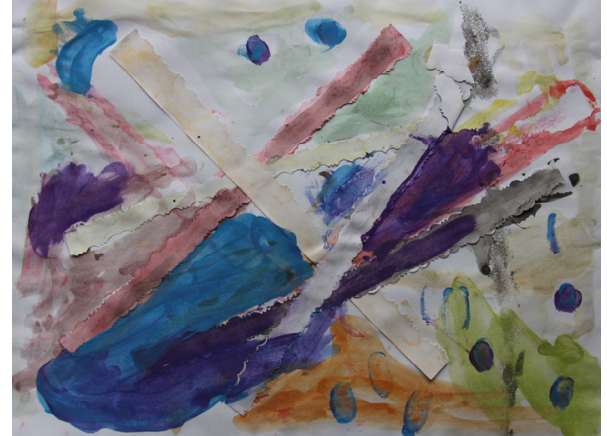

b. S42, 24 x $32 \mathrm{~cm}$,

mixed technique

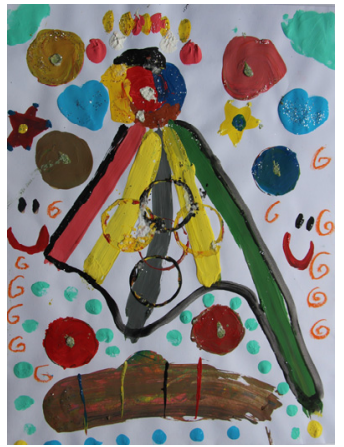

c. $\mathrm{S} 39,24$ x $32 \mathrm{~cm}$,

watercolor technique

Figure 3. Student Works with Different Design Subjects

The students mostly preferred to paint tangible subjects in their designs. We see tangible applications in Figure 3.b where mixed technique is used; as well as in 3.c which was painted with watercolor technique. Landscape design is found to be the mostly preferred subject in students' works, as seen in Figure 3.a.

When Table 5 is analyzed, it is found that students mostly preferred the objects of sun and cloud by $7.83 \%$, while designing the envelope. The second most preferred drawing, on the other hand, is found to be human figure by $7.22 \%$. These are respectively followed by tree and flower by $6.02 \%$; grass and house by $4.81 \%$; heart and star by $4.21 \%$; Turkish flag by $3.61 \%$; rainbow and road by $3.01 \%$; and bird sketches by $2.40 \%$. According to Table 5 , the least preferred drawings are found to be octopus, horse, gift package, moon and star, fish, cartoon character, tooth, earth, hand, apple, ship, watermelon, cottage, skull, pit, table, park, orange, clock, and ladybug by $0.61 \%$. 
Table 5. Distribution of Objects Used by Students While Designing the Envelope

\begin{tabular}{|c|c|c|c|c|c|}
\hline Object & $\mathrm{f}$ & $\%$ & Object & $\mathrm{f}$ & $\%$ \\
\hline Tree & 10 & 6.02 & Sun & 13 & 7.83 \\
\hline Octopus & 1 & 0.61 & Gift package & 1 & 0.61 \\
\hline Car & 3 & 1.80 & Heart & 7 & 4.21 \\
\hline Horse & 1 & 0.61 & Snowman & 3 & 1.80 \\
\hline Moon Star & 1 & 0.61 & Watermelon & 1 & 0.61 \\
\hline Fish & 1 & 0.61 & Cat & 4 & 2.40 \\
\hline Balloon & 2 & 1.20 & Butterfly & 3 & 1.80 \\
\hline Cloud & 13 & 7.83 & Dog & 2 & 1.20 \\
\hline Flower & 10 & 6.02 & Cottage & 1 & 0.61 \\
\hline Grass & 8 & 4.81 & Skull & 1 & 0.61 \\
\hline Cartoon character & 1 & 0.61 & Bird & 4 & 2.40 \\
\hline Mountain & 2 & 1.20 & Pit & 1 & 0.61 \\
\hline Marine & 3 & 1.80 & Table & 1 & 0.61 \\
\hline Dinosaur & 2 & 1.20 & Park & 1 & 0.61 \\
\hline Tooth & 1 & 0.61 & Orange & 1 & 0.61 \\
\hline $\begin{array}{l}\text { Figures that do not } \\
\text { correspond to nature }\end{array}$ & 3 & 1.80 & Rocket & 3 & 1.80 \\
\hline World & 1 & 0.61 & Watch & 1 & 0.61 \\
\hline Hand & 1 & 0.61 & Turkish flag & 6 & 3.61 \\
\hline Apple & 1 & 0.61 & Ladybug & 1 & 0.61 \\
\hline House & 8 & 4.81 & Airplane & 3 & 1.80 \\
\hline Figure (Human) & 12 & 7.22 & Writing & 3 & 1.80 \\
\hline Ship & 1 & 0.61 & Road & 5 & 3.01 \\
\hline Planet & 2 & 1.20 & Star & 7 & 4.21 \\
\hline Rainbow & 5 & 3.02 & Total & 166 & 100 \\
\hline
\end{tabular}

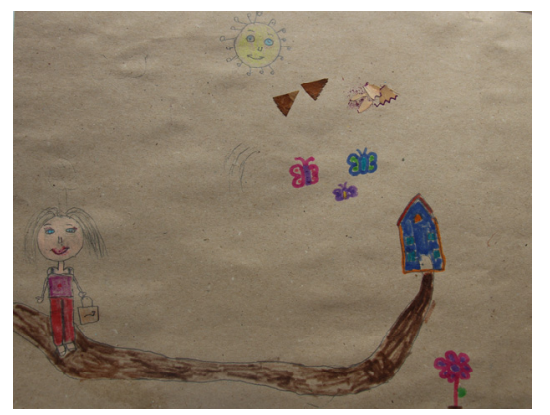

a.S7, $24 \times 32 \mathrm{~cm}$, mixed technique

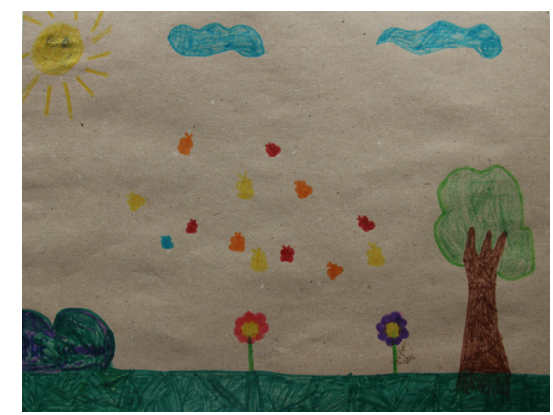

b. S8, $24 \times 32 \mathrm{~cm}$, felt marker

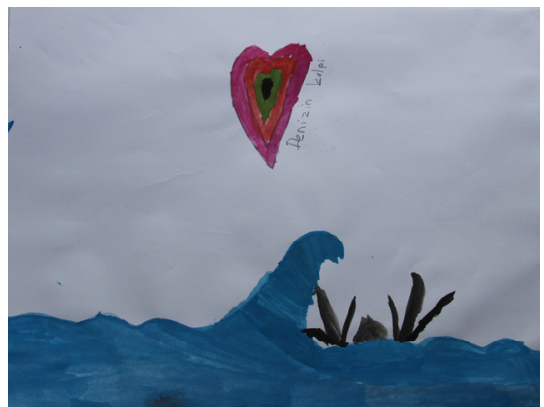

c. S26, 24 x $32 \mathrm{~cm}$, watercolor technique

Figure 4. Student Studies Designed with Drawing of Various Objects

Figure 4.a shows us that the student used human figure, which is the most preferred object. We see tree and flower in 4.b, and heart in 4.c. Given the authenticity they showed while depicting an object on the envelope, it is possible to suggest that the works of students reflect their creative aspects. 


\subsection{The Findings Obtained from the Students' Opinions on Mail Art}

Students were asked what they had drawn on the envelope they designed during the mail art activity, and what they intended to tell. Based on their statements, it can be suggested that the students designed their envelopes as they expressed. Some of the students' statements are as follows:

"I narrated love " (S3).

"I wanted to draw something mixed" (S4).

"I drew a normal picture" (S7).

"I drew a forest " (S8).

"I drew a battlefield" (S9).

"I drew cities and the earth " (S11).

"Life of dinosaurs and planets " (S16).

"I drew cats and cottages " (S28)

"I wanted to embellish" (S33).

"I drew through improvisation" (S41)

"I did not have any particular intention. I just painted it." (S42)

When these statement are reviewed, it can be clearly seen that students are able to state their thoughts and intentions about their paintings frankly.

In order to find out the effect of the mail art activity, conducted in Fine Arts course, the students were asked whether they liked the activity or not. Some of the answers given by the students are:

"I liked this work very much. I enjoyed it and it made me happy. I love cutting and pasting." (S3).

"I really enjoyed this activity. Because I was able to improvise." (S4)

"I had a lot of fun, it turned out to be beautiful with regular painting" (S7)

"I love it because it is colorful" (S15)

"It was fun because we experienced something new" (S20)

"It was beautiful, we created a work of art" (S24)

"It was amazing. I liked it very much because I had the chance to learn about mail art." (S27)

"The mail art turns out to be the shaping of an envelope, and I had a lot of fun" (S30)

"Very nice, I liked it a lot. From this moment on, I will definitely embellish the envelope whenever I write a letter" (S33)

"I love it, we adorned the envelope as we wish " (S34)

"I loved this particular art" (S38)

"It was fun, This art involves envelopes with beautiful pictures on it. (S39)

"I liked it. I wish we could always do such fun activities" (S42)

The statements above reveal that all the students liked the activity. It can be observed that they particularly expressed their joy, love, and happiness.

\section{Discussion}

According to the results obtained from the study, all students liked the activity of mail art, and they made authentic drawings while deigning envelopes. The students were asked whether they had an idea about the mail art prior to the study, and they stated that they had never heard of it before. They had the knowledge about each concept when asked separately; while they were not aware of it as a form of art. They also added that they had never tried such an activity in class before. It is observed by the researcher that trying new and different things led to an enthusiasm and eagerness among students. In the first hour of the course, students were given a general information about contemporary art practices and mail art; as well as demonstrating exmaples of mail art on projection. Students were informed about the materials they needed to bring for the next course. Second hour was the practice phase where 
students were initially nervous, but then relaxed and designed the envelopes handed to them with excitement and eagerness. Works of the students were collected at the end. As Özsoy (2003, p. 50-51) suggests, visual arts bring enthusiasm and dynamism to the process of learning. Students become more engaged in learning, they add new dimensions to their knowledge, and the learning process is enhanced. Lask and Mukerji-Bergeson (2003) asserted that carefully-designed and engaging activities promote children's way of learning (cited in Fox \& Schirrmacher, 2014, p. 155).

Works of the students were interpreted as descriptive, in terms of technique, subject matter, and the objects they used. In line with the findings obtained, it can be suggested that a vast majority of students $(44.18 \%)$ preferred to use a mixed technique. It is observed that they especially enjoyed using the waste materials they brought. Secondly, 25.58\% of students preferred to use watercolor. It is also remarkable that the students already owned watercolors but never had the chance to use it before, so they expressed their desire to use them. They associate this desire with not using this type of painting before. The least preferred technique turned out to be charcoal drawing. Miller (1996) stated that the objects of art education involves enabling children to work with natural objects and to express their feelings and thoughts through different art materials, as well as developing their creativity. According to Fox and Schirrmacher (2014, p. 194), "providing appropriate art materials for children is a way of telling them that they are actually creative artists and they can produce nice works when given the right materials".

In the study, it is observed that most of the students (74.42\%) designed both sides of the envelopes given. Subject matters preferred by the students while designing their envelopes revealed that $41.86 \%$ of them chose tangible subjects. They also supported their envelope designs, created with the use of colors and shapes, with their own words. They reflected their inner worlds in a way that is specific to them as they wish through statements such as "....I improvised..."...I just wanted to paint," "I did what I love the most: cutting and pasting". Landscape-nature is found to be the second most preferred $(27.90 \%)$ subject to be drawn. It is also remarkable that there are differences in subject matters. Besides the subjects such as space, dinasours, war, love and sea, there were also envelope designs based solely on embellishment. According to Kırışoğlu (2002, p. 175), the process of artistic creation is the process of problem solving. In other words, it is the arrangement of relationships between color, line, texture, gap and etc. through thinking, in order to reach the desired quality. This way, the artistic problem will be solved and an artistic creation will be achieved.

When the objects used by the students while chosing a subject matter are analyzed, sun and cloud is found to be the most preferred object. This is followed by figure $(7.22 \%)$, tree $(6.02 \%)$, flower $(6.02 \%)$, grass $(4.81 \%)$, house (4.81\%), heart (4.21\%), star (4.21\%), Turkish flag (3.61\%), rainbow (3.02\%) and road (3.02\%), respectively. These objects are observed to be involved mostly in landscape-nature drawings. It is possible to claim that students used different and various objects while designing envelopes. Some students are observed to have used objects or figures that did not correspond to nature. It is also remarkable that they expressed themselves freely in their designs, as they wished. According to Fox and Schirrmacher (2014, p. 169), art education reinforces intuition, reasoning, imagination, self-expression, and communication skills of children.

It is also obvious that students supported their designs with their statements. At the same time, the excitement and desire observed during the application process were also present in their opinions on this activity. All of the students welcomed the mail art and expressed their fondness and happiness. Especially, there are statements such as "I wish there were such activities all the time." In this respect, it can be suggested that the mail art was effective on students and increased the interest in the course. Within this context, ensuring the acquisition of knowledge on contemporary art practices, experiencing the process of producing works of art, increasing the interest in the course by organizing different activities, and enabling them to learn the concepts such as art, artist and work of art effectively, are of great importance in terms of giving a modern aspect to Visual Arts course.

In line with this study, the following suggestions have been developed:

- Mail art activity can be applied in different grades, and further research may be performed regarding its reflection to their works.

- Further research can be conducted to analyze the attitude of students towards the practice of mail art and visual arts course.

- Further research on the effect of mail art activity on academic achievements of students can be conducted.

- Students can be given the opportunity to participate in mail art competitions or exhibitions organized in our country with the works they created during the mail art activity, and student opinions can be considered. 
- The subject of mail art can be included in the curriculums of the Faculties of Fine Arts and Departments of Fine Arts Education in Universities; as well as conducting practice studies and consideration of student opinions. .

\section{References}

Alaca, I. V. (2014). "Posta Kutusunda Sanat” [Art In A Mail Box]. Posta Sanatı [Mail Art]. (Ed. Şinasi Güneş). 74-85. İstanbul: Artes Publishing.

Atalay, M. C., \& Gürses, B. (2016). "Yükseköğretim Sanat Eğitiminde Posta Sanatı Uygulamalarl” [Mail Art Applications in Fine Arts Education of Higher Education], Cumhuriyetin Işığında Yükseköğretimde Sanat Eğitimi Uygulamaları Sempozyumu [Symposium on Art Education Applications in Higher Education In The Light Of The Republic], Gazi University Gazi Faculty of Education Department of Painting, 23-25 November 2016, 623-637. $\quad$ Retrieved 20.01 .2018 from https://www.academia.edu/35690652/Y\%C3\%9CKSEK $\%$ C3\%96\%C4\%9ERET $\%$ C4\%B0M_SANAT_E $\%$ C4\% $9 \mathrm{E} \% \mathrm{C} 4 \% \mathrm{~B} 0 \mathrm{~T} \% \mathrm{C} 4 \% \mathrm{~B} 0 \mathrm{M} \% \mathrm{C} 4 \% \mathrm{~B} 0 \mathrm{NDE}$ POSTA SANATI UYGULAMALARI

Dunkin-Hubby, L. (2016). A Brief History of Mail Art's Engagement With Craft (c. 1950-2014). The Journal of Modern Craft, 9(1), 35-54. https://doi.org/10.1080/17496772.2016.1183948

Erişti, S. D. B. (2016). “Bir Anlatı Biçimi Olarak Görsel Araştırma Yöntemleri” [Visual Research Methods As A Form Of Narrative]. In Suzan Duygu Bedir Eriști (Ed.), Görsel Araștırma Yöntemleri Teori, Uygulama ve Örnek [Visual Research Methods Theory, Application and Example], 156-166. Ankara: Pegem Publishing.

Fox, J. E., \& Schirrmacher, R. (2014). Art \& Creative Development for Young Children. (Trans. Neriman Aral \& Gökhan Duman). Ankara: Nobel Publishing.

Frank, P. (1981). Postal Modernism Artists' Stamps and Stamp Images. Retrieved 20.02.2019 from http://www.artpool.hu/Artistamp/PFranke.html

Friedman, K. (1995). The Early Days of Mail Art An Historical Overview. Retrieved 20.01.2018 from https://s3.amazonaws.com/academia.edu.documents/37215897/Friedman_1995 The_Early_Days_of_Mail_Art 150405 .pdf?AWSAccessKeyId=AKIAIWOWYYGZ2Y53UL3A\&Expires $=\overline{15} 47954012 \&$ Signature $=$ OX $\overline{-}$ 6Qn T8HR7dj3XwfDFj9LKrdcug\%3D\&response-content-disposition=inline\%3B\%20filename\%3DFriedman._1995 ._The_Early_Days_of_Mail_A.pdf

Gangadharan, S. P. (2009). Mail Art: Networking Without Technology. New Media \& Society, 11(1-2), 279-298. https://doi.org/10.1177/1461444808099581.

Güneş, Ş. (2014). Posta Sanatı [Mail Art]. İstanbul: Artes Publishing.

Karasar, N. (2008). Bilimsel Araştırma Yöntemi [Scientific Research Method]. Ankara: Nobel Publishing.

Kehnemuyi, Z. (1995). Çocuğun Görsel Sanat Eğitimi [Visual Art Education of the Child]. İstanbul: Yap1 Kredi Publishing.

Kırışoğlu, O. T. (2002). Sanatta Eğitimi-Görmek Öğrenmek Yaratmak [Seeing, Learning and Creating Education in Art]. Ankara: Pegem Publishing.

Merriam S. B. (2015). Nitel Araştırma Desen ve Uygulama İçin Bir Rehber [A Guide To Qualitative Research Pattern and Application]. (Trans. Selahattin Turan). Ankara: Nobel Publishing.

Miller, R. (1996). The Developmentally Appropriate Inclusive Classroom in Early Education. U.S.A.: Delmar Publishers.

Özsoy, V. (2003). Görsel Sanatlar Eğitimi Resim-İs Eğitiminin Tarihsel ve Düşünsel Temelleri [Historical and Intellectual Foundations of Art Education of Visual Arts Education]. Ankara: Gündüz Education and Publishing.

Paker, T. (2015). "Durum Çalışması" [Case Study]. In Fatma Nevra Seggie \& Yasemin Bayyurt (Eds.), Nitel Araştırma Yöntem, Teknik, Analiz ve Yaklaşımlarl [Qualitative Research Method, Technique, Analysis, and Approaches], 123-134. Ankara: Anı Publishing.

Phillpot, C. (1995). The Mailed Art of Ray Johnson. Eternal network: A Mail Art Anthology. Retrieved 20.02.2019 from http:/www.artpool.hu/Ray/Publications/Phillpot.html

Punch, K. F. (2005). Sosyal Araştırmalara Giriş Nicel ve Nitel Yaklaşımlar [Introduction to Social Researches: Qantitative and Qualitative Approaches]. (Trans. Dursun Bayrak, H. Bader Arslan \& Zeynep Akyüz). Ankara: 
Siyasal Bookstore.

Siegesmund, R. (1998). Why Do We Teach Art Today?. Studies in Art Education, 39(3), 197-214. https://doi.org/10.1080/00393541.1998.11650024

Yıldırım, A., \& Şimsek, H. (2003). Sosyal Bilimlerde Nitel Araştırma Yöntemleri [Qualitative Research Methods in Social Sciences]. Ankara: Seçkin Publishing.

Yılmaz, M. (2010). "Sanat Eğitiminde Motivasyon Sanat Eğitiminde Kopya ve Taklit Görsel Sanatlarda Teknik ve Yöntemler" [Motivation in Art Education Copying and Imıtation in Art Education Technique and Methods in Visual Arts]. In Kazım Artut (Ed.), Güzel Sanatlar Ĕgitiminde Özel Öğretim Yöntemleri [Special Teaching Methods in Fine Arts Education], 195-298. Ankara: Anı Publishing.

Yılmaz, M. G. (2009). "Görsel Sanatlar Eğitimi” [Fine Arts Education]. In Ali Osman Akkuş \& Levent Mercin(Ed.), Sanat Eğitimi ve Görsel Sanatlar Öğretimi [Art Education and Teaching Visual Arts], 13-18. Ankara: Pegem Publishing.

Yolcu, E. (2010). "Sanat Eğitiminde Yaratıcılık" [Creativity in Art Education]. In Kazım Artut (Ed.), Güzel Sanatlar Ĕgitiminde Özel Öğretim Yöntemleri [Special Teaching Methods in Fine Arts Education]. 31-89. Ankara: Anı Publishing.

Zimmerman, E. (2009). Reconceptualizing the Role of Creativity in Art Education Theory and Practice. Studies in Art Education, 50(4), 382-399. https://doi.org/10.1080/00393541.2009.11518783 